\title{
Study on Integrated Monitoring System for Protecting Water Pollution
}

\author{
Jae Soo Yang ${ }^{1}$, Yoon Hyun Kim², Yong Hwan $\mathrm{Han}^{3}$, Young Ha Lee ${ }^{4}$, and Jin Young Kim²*
}

접수: 2009년 10월 3일 / 게재승인: 2011년 4월 12일

(C) 2011 The Korean Society for Biotechnology and Bioengineering

\begin{abstract}
The conventional monitoring system for water pollution measurement is quite simple and independent and it has a lot of draw backs such as cost, installation, etc. So, in this paper, we have measured the water pollution system through a bacterial species, photobacterium phosphoreum. A novel integrated monitoring system technology has been developed which could easily dictate and analyze the major water pollutants and its surrounding environment in an accurate way. The system constitutes of bionic technology, information technology and environmental engineering technology. As a result, integrated monitoring system can observe the water pollution and various water environment of the whole country. Also, through the sensors of USN, Zigbee, RFID and middle ware, which can provide service and construct service platform, a properly standardized plan with remarkable service platform has been established through this investigation.
\end{abstract}

Keywords: Integrated monitoring system, Water pollution, Ubiquitous sensor network (USN), B-TOX

\footnotetext{
${ }^{1}$ 경기도청/광운대학교

${ }^{1}$ The Governor's Advisor, Gyeonggi Province/Kwangwoon University

${ }^{2}$ 광운대학교

${ }^{2}$ Kwangwoon University

Tel: +82-2-940-5567, Fax: +82-2-918-0357

e-mail: jinyoung@kw.ac.kr

${ }^{3}$ 워터바이오

${ }^{3}$ WaterBio Co., LTD.

4충남대학교

${ }^{4}$ Chungnam National University
}

\section{1. 서론}

산업의 발전이 우리에게 주는 여러 이점들의 이면에는 환경 오염이라는 해결해야 할 숙제 또한 존재한다. 그 중 하나가 하천 및 강으로 유입되는 유해물질에 대한 처리문제이다. 현대 산업의 발전에 따른 수중으로의 유해물질 유입은 그 종류와 양이 증가되고 있으며, 이에 따른 안전한 수자원확보 에 대한 요구가 지속적으로 제기되고 있다 [1,2]. 특히 오염 물질의 종류와 양을 알기 힘들거나 여러 가지 오염물질에 의해 오염된 경우는 현재 수질평가를 위한 일부 분석항목만으로는 정확한 오염원인의 분석 및 인체, 생물에 대한 유해성 판단 에 어려움이 있다 [3]. 그러므로 이에 대한 대책으로 독성물 질에 민감한 생물들을 이용하여 인체에 미치는 영향을 유추 해내고 미지의 오염물질에 의한 사고를 단시간 내에 방지할 수 있는 생물경보시스템을 필요로 하고 있다 $[4,5]$.

생물경보시스템이란 수계에 유입되는 독성물질에 대한 생물반응을 실시간으로 감시하는 경보시스템을 말한다. 즉, 생물을 이용한 생물경보시스템이란 살아있는 생물체의 물 리적, 생리적 반응을 이용하여 화학물질이 생물체에 미치는 독성적인 영향을 생물경보장치를 통하여 지속적으로 예측. 측 정함으로써 생물체의 대량 사멸이나 생태계 변화가 일어나기 전에 측정 data를 분석, 경보하는 역할을 하는 통합적 시스템 을 말한다. 나아가 생물에 위해가 있을 경우 현장과 중앙관제 시스템에서 경보를 알려 최단시간에 오염방제조치를 실시할 수 있도록 하는 통합수질모니터링시스템이라고 할 수 있다 [6].

최근, 생물경보시스템의 일종으로 미생물의 발광 현상을 이용한 유해 물질의 분석 및 경보 방법이 각광 받고 있으 며, 미생물의 반응이 빠르고 유지비용이 다른 생물경보시 스템에 비해 적게 들며, 해당 미생물이 수질에 아무 영향 을 미치지 않는다. 발광 미생물로는 Vibrio, Photobacterium, Altenomonas, Xenorhabus 속의 균주들이 잘 알려져 있으며, 
이들은 luciferase에 의한 반응 결과, bioluminescence를 발생 한다. 발광 미생물이 유해 물질에 노출될 경우, bioluminescence 발생 메카니즘에 영향을 받아 bioluminescence가 감소하게 된다. 이와 같은 감소 반응은 매우 짧은 시간에 일어나며, 아주 극소량의 유해물질에도 반응하므로 발광 미생물의 bioluminescence를 모니터링 하여 수질 관리를 할 수 있다 [7-9].

본 논문에서는 발광미생물을 이용한 수질오염 감시 시스템 에 대한 연구 및 분석을 하였으며, 이는 상류에서 하류로 이어 지는 동선을 따라 하천의 지역 및 권역별 수질변화를 측정하 고 분석하여 오염을 막을 수 있는 통합 모니터링 시스템 (W$\mathrm{TOX}$ )을 의미한다. 이 시스템은 정보기술 (IT)과 생물공학 기술 (BT) 및 환경공학기술 $(\mathrm{ET})$ 의 융합체로 구성된 최첨단 장비로서, 365 일 동안 전 자동 무인운전으로 유해물질 감지 능력을 보유하고 있다. 또한 이는 상류에서 하류로 이어지는 동선을 따라 하천의 지역 및 권역별 수질변화를 측정하고 분석하여 오염을 막을 수 있는 시스템이다. W- TOX 시스템 은 수질에 1000 여종 이상의 오염물질을 대상으로 오염물질 이 들어오면 즉시 인식하여 중앙 시스템에 통보한다. 예를 들 어, 수돗물 원수 취수장에 중금속, 농약, 축산폐수, 기름류 등 이 들어오면 1 5분안에 기계가 자동으로 경보음을 울리고, 담당 공무원의 $\mathrm{PC}$, 핸드폰으로 즉시 알려, 취수중단을 시켜 큰 재앙을 사전에 막을 수 있는 최첨단 시스템이다.

또한 본 논문에서는 W- TOX 시스템을 원주 취수장에 설 치하여 다이옥산 농도에 따른 시스템의 조기 경보 성능을 조사한 실험결과를 보여준다. 다이옥산 농도에 따라서 경보 발생 시간이 단축됨을 확인하였으며, 이렇게 발생한 경보는 통합 모니터링 시스템을 통해 문자, 전광판 등을 통해 즉시 전달되어 즉각적인 처리가 가능함을 알 수 있다.

\section{2. 시스템 구성 및 특징}

\section{1. 시스템 구성}

본 연구의 수질오염 감시 시스템에서는 Photobacterium phosphoreum 이라는 발광성 해양미생물을 이용한다. 본 시스템은 독성물질이 들어오면 미생물에서 발산되는 빛의 양 이 현저하게 줄어들어 컴퓨터 모니터에 경보음을 울리도록 하는 원리를 이용하며, 이 미생물은 약 1000 여종 이상의 유해물질 감지능력을 보유하고 있는 것으로 알려져 있다. 기존의 생물조기경보시스템으로는 물고기, 물벼룩 등을 이용 한 방법들이 활용되고 있으나, 2008년 3월 낙동강 폐놀유출 사고, 2006년 낙동강 유독물질 오염 사고 발생 시 그 기능을 전혀 나타내지 못한 것으로 알려져 있다.

위의 Fig. 1은 발광 미생물을 이용한 수질오염 감시 시스 템으로 명칭은 $\mathrm{W}-\mathrm{TOX}$ 으로, 정보기술 (IT) + 생물 공학기술 (BT) + 환경공학기술 $(\mathrm{ET})$ 의 융합체로서 최첨단 기계이며, 365 일 동안 전 자동 무인운전으로 유해물질 감지능력을 보유 하고 있다. 또한 이는 상류에서 하류로 이어지는 동선을 따라 하천의 지역 및 권역별 수질변화를 측정하고 분석하여 오염을 막을 수 있는 시스템이다. W- TOX 시스템은 수질에 1300여 종의 오염원이 들어오면 즉시 인식하여 중앙 시스템에 통보
한다. 예를 들어, 수돗물 원수 취수장에 중금속, 농약, 축산 폐수, 기름류 등이 들어오면 1 5분안에 기계가 자동으로 경보음을 울리고, 담당 공무원의 $\mathrm{PC}$, 핸드폰으로 즉시 알려, 취수중단을 시켜 큰 재앙을 사전에 막을 수 있는 최첨단 시스 템이다. 또한 손쉽게 설치가 가능하여 대운하, 하천, 호수, 수돗물 취/정수장, 하/폐수처리장, 골프장, 방사능 유출지역, 화장품 독성 테스트, 음료수/식품성 톡성 테스트 등의 오염원 발생이 가능한 모든 지역에 설치가 가능하다.

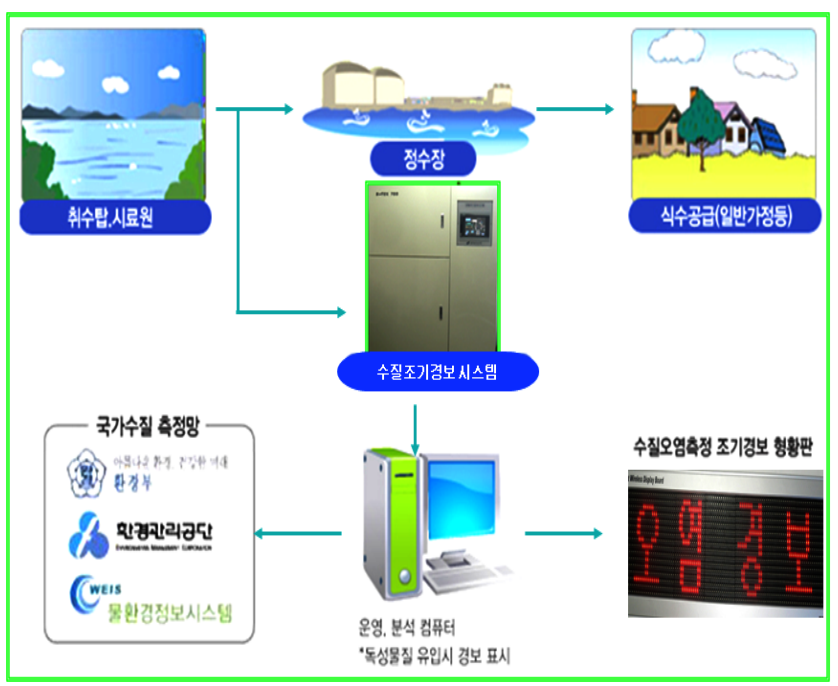

Fig. 1. Process of the early warning system.

전체 시스템의 구성도 및 특징을 살펴보면 다음과 같다.

(1) Ubiquitous 기반의 시스템으로 손쉬운 배포 및 설치를 통하여 광범위한 지역의 수변환경에 대한 다각적인 측정 및 감시 가능.

(2) 수변을 포함한 하천을 체계적으로 관리하기 위한 생물 오염경보, 수온, 유속, 탁도, $\mathrm{BOD}, \mathrm{COD}, \mathrm{PH}$ 등의 다양 한 센서 데이터를 취득하고, 취득된 데이터에 대해 분석 과 판단이 가능.

(3) IPv6 기반의 양방향 시스템으로 포괄적인 웹 기반 통합 관제 및 통제 시스템.

(4) 생물학적 실시간 수질오염 측정 및 경보를 이메일, 휴대폰 SMS, 시스템 notification 등의 다양한 알림 시스템과 연동 또한 통합 관제 및 제어 구성은 Fig. 2와 같으며 그 내용은 다음과 같다.

(5) 각 지역에 분산 설치된 측정 시스템을 헤트쿼터에서 통합 관제.

(6) 측정되는 오염경보, 수온, 유속, 탁도, $\mathrm{BOD}, \mathrm{COD}$ 등 다수의 데이터들이 실시간으로 통합 관제서버에 저 장 및 표출.

(7) 측정 데이터들을 분석하여 오염에 대한 위험이 있다 고 판단될 시 자동으로 휴대폰 SMS나 이메일, 시스템 notification 등으로 관리자에게 전달.

(8) 센서에서 통합관제서버까지 IPv6 프로토콜 기반으로 통신. 


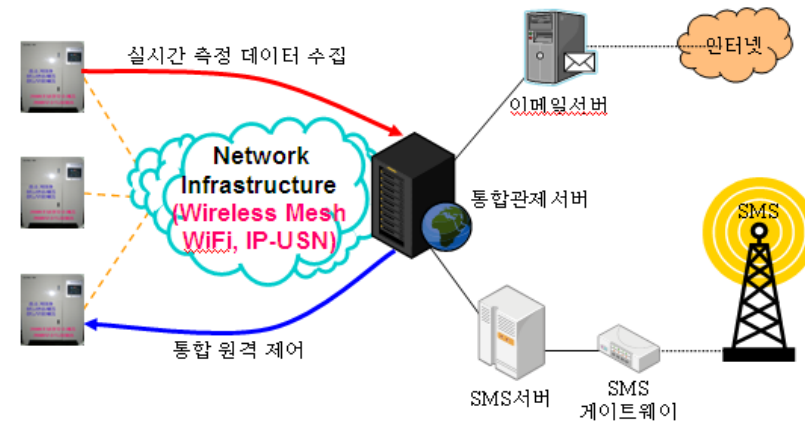

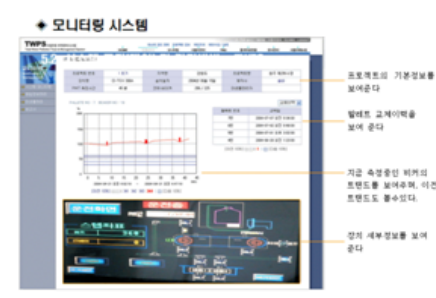

B-TOX 모니터링 시스템

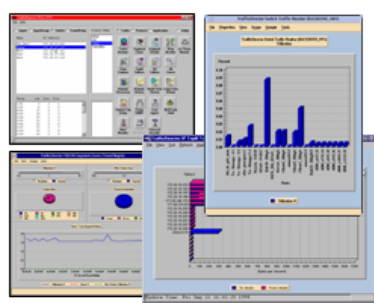

측정 자료 분석의 예
Fig. 2. Organization of the integrated monitoring system.

\section{2. 시스템 특징}

경기도 한강수계 내 40 개 지천에 설치되는 자동측정기, 각종 USN 센서 네트워크에서 실시간으로 수집, 제공되는 대량의 정보를 분석 처리하기 위한 EDA (Event Driven Architecture) 기반의 차세대 융합 통합 서비스 플랫폼 제공한다. 또한 실 시간으로 수집되는 다양하고 상이한 대량의 정보들 간의 상호 연관성을 분석하고 복합적으로 지능적인 처리를 위해 SOA (Service Oriented Architecture) WebService/JMS/J2EE 기반의 대내/외적인 환경변화에 민첩하게 대응하는 ESB (Enterprise Service BUS) 플랫폼으로 구축하여 보다 좋은 성능을 보여 준다. 그리고 실시간으로 수집, 분석된 수자원 정보들은 통합 모니터링 플랫폼에 의해 관련 기관 및 담당자들에게 효율적 으로 배포 및 활용을 위한 정보의 백본 관리 기능을 제공한고 Complex Event Cloud (혼재 데이터) 속에서 의미 있는 데이
터를 감지하고, 단순/복합 데이터 분석, 응답 등 새로운 이벤 트 데이터를 생성하여, 유관관계자에게 전달하는 이벤트 중심 의 수질정보 연계통합 플랫폼 기반의 통합 모니터링 시스템 구축한다. 이러한 기능들은 Fig. 3의 통합 모니터링 시스템 특징에 잘 나타나있으며 기존 시스템과 차별성을 갖는 다음 Table1과 같은 기능을 포함하고 있다.

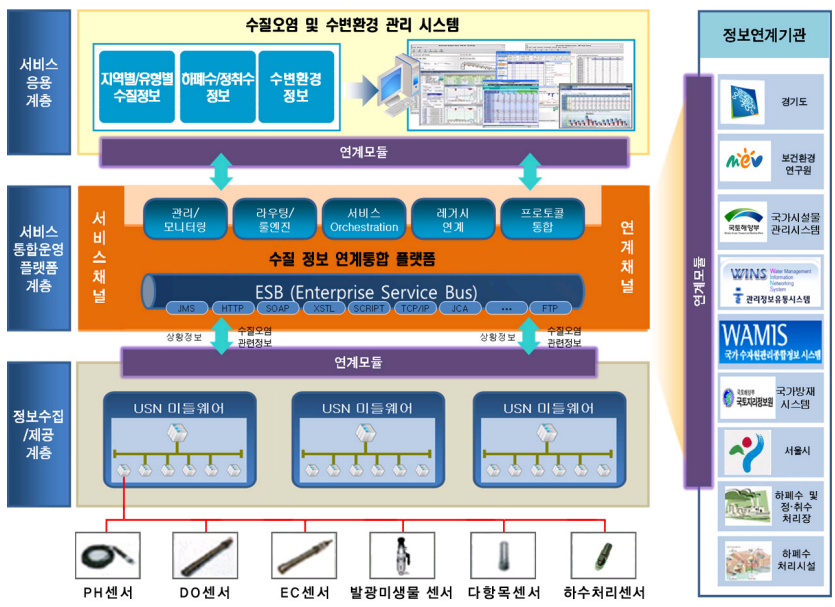

Fig. 3. Characteristic of the integrated monitoring system.

\section{3. 실험 방법 및 결과}

본 연구에서는 여러 장소에 수질 자동 측정기를 설치하였으 며 원주 취수장 측정기 지점에서의 성능을 보여주고자 한다. 기존의 연구는 1995 년부터 생물 경보장치인 물벼룩 시스템 을 설치 운영하여 왔으나, 오염을 찾아내지 못해 경보 실적 이 전혀 없는 상태이다. 하지만 본 연구에서는 2004년 7월 14 일 원주 취수장에서 경보 발생한 원수를 국가인증센터인 상지대학교에 수질 분석을 의뢰한 결과, 알루미늄이 기준치 $(0.2 \mathrm{mg} / \mathrm{L})$ 보다 높은 $0.34 \mathrm{mg} / \mathrm{L}$ 로 확인되었다.

Fig. 4는 2004년 7월 14일 원주 취수장에서의 실제 WTOX 발광값 변화 그래프로 수질 오염에 따른 발광 미생물

Table 1. Differentiated service of the integrated monitoring system

\begin{tabular}{|c|c|}
\hline 기능명 & 설 $\quad$ 명 \\
\hline $\begin{array}{l}\text { 실시간 대용량 } \\
\text { 데이터 처리 }\end{array}$ & $\begin{array}{l}\text { - 센서 데이터에서 발생되는 대용량의 데이터 수집/처리 기술 } \\
\text { - 실시간으로 대용량 발생되는 데이터의 현재 상태의 정확한 분석 } \\
\text { - 실시간 데이터 처리 } \\
\text { - 실시간 데이터 패턴 추출 } \\
\text { - 다양한 아키텍처 구성 지원 }\end{array}$ \\
\hline $\begin{array}{l}\text { 이벤트 생성 기능 } \\
\text { 제공 }\end{array}$ & $\begin{array}{l}\text { - 상황인지 기반 Rule엔진 통해 수질 환경 관련 이벤트 } \\
\text { (오염도알림정보, 폐수유출 추정)를 생성 제공 } \\
\text { - 수질 관리 제어정보를 관련 관리시스템/관리자에 제공 }\end{array}$ \\
\hline $\begin{array}{l}\text { 이기종 시스템간의 } \\
\text { 실시간 연계 }\end{array}$ & $\begin{array}{l}\text { - 센서 데이터 및 가동된 정보의 배포 및 수집을 이기종 시스템을 대상으로 실시간 상호 연계 기능 제공 } \\
\text { - 이기종 시스템 통신 프로토콜 브릿징 기능 (어댑터)제공 } \\
\text { - 다양한 데이터의 변환을 위한 정보 변환/가공 모듈기능 }\end{array}$ \\
\hline $\begin{array}{l}\text { 실시간 데이터 처리 } \\
\text { 및 모니터링 }\end{array}$ & $\begin{array}{l}\text { - 수질 환경 관련 정보(센서 데이터)의 상황 및 변경 정보를 사용자에게 실시간으로 웹기반의 브라우저를 통해 제공 } \\
\text { - 관리자 (사용자)가 웹을 통하여 원격 모니터링 및 제어할 수 있는 기능 제공 } \\
\text { - SMS를 통한 담당자 자동 알림 및 통보 기능 제공 }\end{array}$ \\
\hline $\begin{array}{l}\text { 수질 정보 분석 및 } \\
\text { 통계 기능 }\end{array}$ & $\begin{array}{l}\text { - 다양한 비주얼기능 (그래프) 통한 수질 환경 관련 통계정보 제공 } \\
\text { - 실시간 데이터 분석을 통한 예측 가능 }\end{array}$ \\
\hline
\end{tabular}


빛의 양 감소를 보여준다.

Fig. 5는 원주 취수장에서 경보 발생한 자료를 상지대학교 에 분석을 의뢰를 분석한 결과로서 원수 취수장의 오렴 경보 발생 시 수질 분석 결과표이다. 주요 검사항목으로 알루미늄 을 측정하였으며 기준치 보다 높은 수치를 나타냄을 확인하 였으며, 중온세균, 저온세균, 총대장균군, 살모넬라, 쉬겔라, 냄새, 색도, 탁도 모두 기준을 초과함을 보여준다.

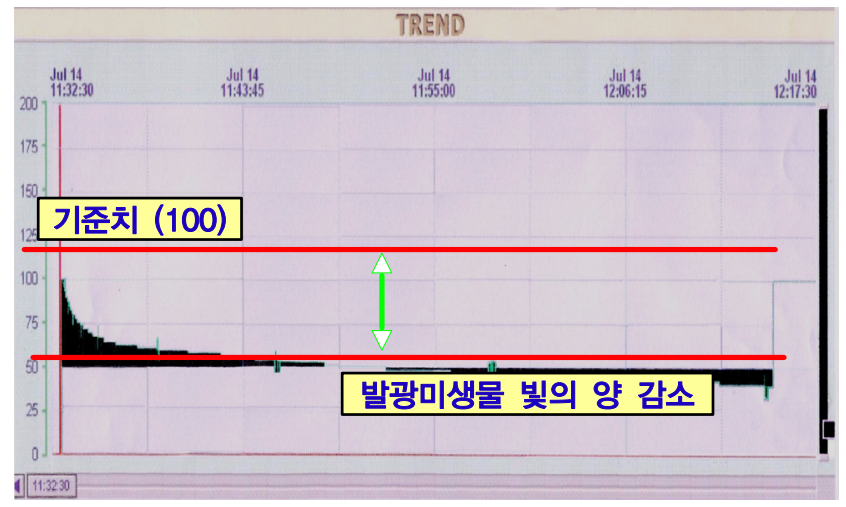

Fig. 4. Variation of luminous value for W-TOX.

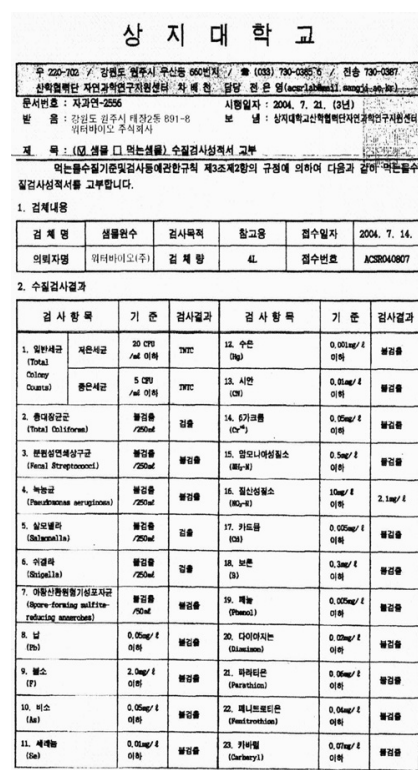

\begin{tabular}{|c|c|c|c|c|c|}
\hline 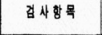 & $x$ & 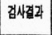 & 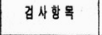 & ग 준 & 즘서년 \\
\hline 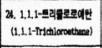 & 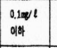 & 諅 & 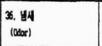 & 啊 & $*$ \\
\hline 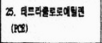 & 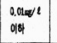 & tos & $\mid \begin{array}{l}n .2 \\
\text { intation }\end{array}$ & 甲9 & 4 \\
\hline 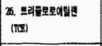 & 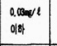 & Hat & s.t. & $\begin{array}{l}\text { wew } \\
\text { ofl }\end{array}$ & ba \\
\hline 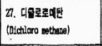 & 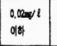 & tot & $\mid \begin{array}{l}3.45 \\
\text { (ioner }\end{array}$ & ssam & $\max$ \\
\hline and & 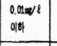 & 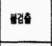 & 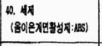 & wit & 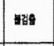 \\
\hline (x) & 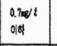 & 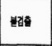 & 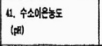 & 58,5 & 1.0 \\
\hline x. & 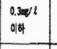 & "was & 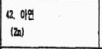 & 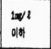 & $0.000 \times 2$ \\
\hline 1) & 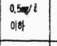 & 培 & 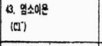 & 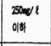 & $w /$ \\
\hline 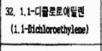 & 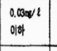 & 路 & 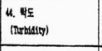 & IRDOA & $11 . \sin$ \\
\hline (2. & 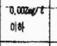 & 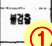 & 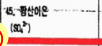 & 年 & $\$$ \\
\hline 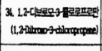 & 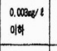 & 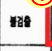 & and & $\begin{array}{l}0.20 \times 11 \\
0.47\end{array}$ & $0.0 \times 0 \times 12$ \\
\hline 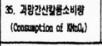 & 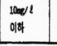 & s. & & & \\
\hline 품 & 형 & & & 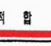 & \\
\hline ه & I & & 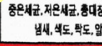 & 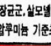 & \\
\hline
\end{tabular}

Fig. 5. Analysis of the water quality.

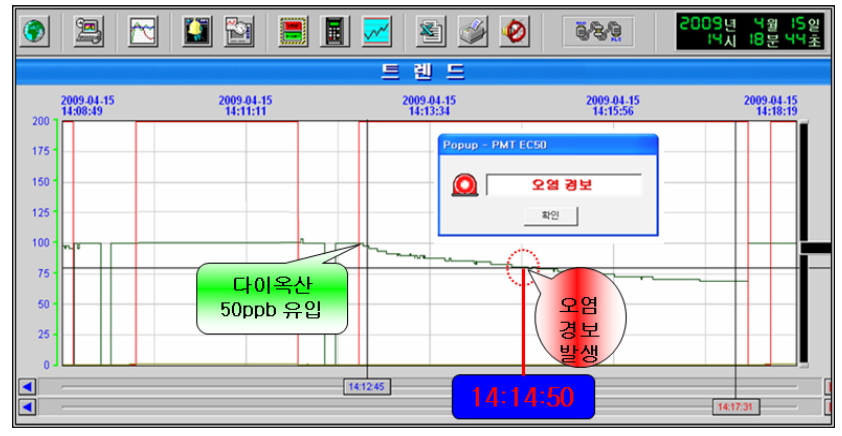

Fig. 6. Measurement of the organic phosphorous dioxane $50 \mathrm{ppb}$.
Fig. 6, Fig. 7, Fig. 8은 2009년 4월 15일 워터바이오 주 식회사 연구 개발실에서 다이옥산 농도가 각각 50,500 , $1000 \mathrm{ppb}$ 일 때의 농도별 실험 내역을 나타나낸다.

Fig. 6은 다이옥산 농도가 $50 \mathrm{ppb}$ 일 때의 측정 실험 결과 로서, 총 측정 시 14 시 12 분 45 초에 다이옥산 $50 \mathrm{bbp}$ 가 유입 되고 2 분 05 초가 지난 14 시 14 분 50 초에 정확히 오염경보가 발생하였음을 알 수 있다.

Fig. 7은 다이옥산 농도가 $500 \mathrm{ppb}$ 일 때의 측정 실험 결과 로서, 총 측정 시 14 시 37 분 20 초에 다이옥산 $500 \mathrm{bbp}$ 가 유입 되고 채 1 분이 되지 않은 시간인 지난 14 시 38 분 15 초에 정확 히 오염경보가 발생하였음을 알 수 있다. 이 결과는 Fig. 6에 서 보여진 결과와 비교하였을 때, 오염물질의 농도가 높아질 수록 보다 빠른 경보가 발생하여 심각한 오염을 조기에 차단 할 수 있음을 보여주는 결과이다.

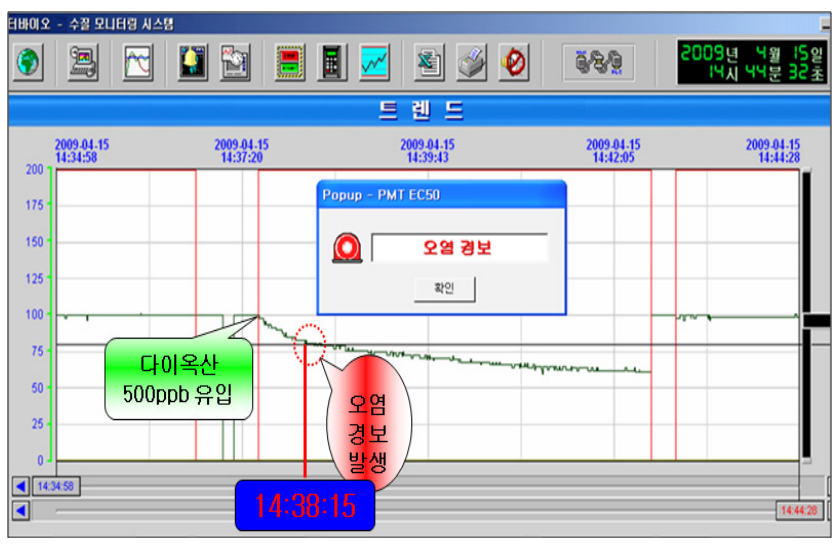

Fig. 7. Measurement of the organic phosphorous dioxane $500 \mathrm{ppb}$.

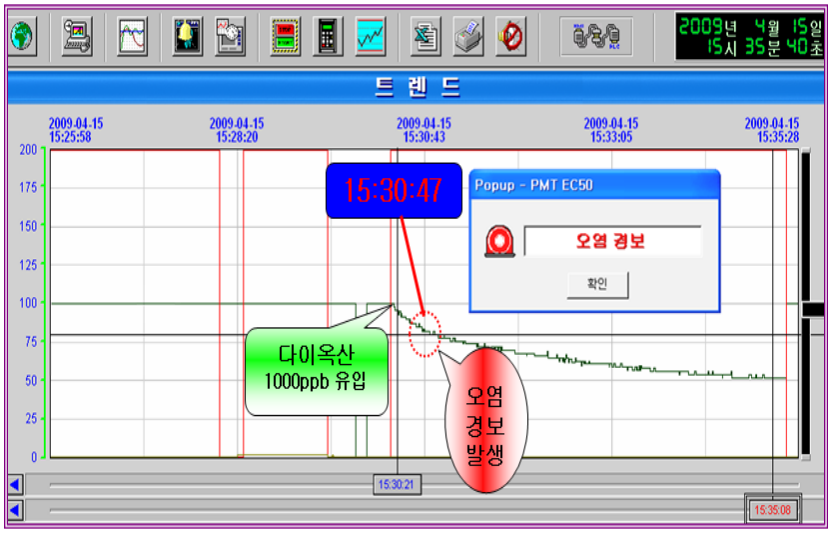

Fig. 8. Measurement of the organic phosphorous dioxane $1000 \mathrm{ppb}$.

Fig. 8은 다이옥산 농도가 $1000 \mathrm{ppb}$ 일 때의 측정 실험 결과로서, 다이옥산이 투입된 후, 불과 26초 만에 정확한 오염 경보를 시스템에 알려주며 앞선 결과 그래프에 비해 보다 정확하고 신속한 조기경보가 가능함을 알 수 있다.

Fig. 6과 Fig. 7, Fig. 8을 통해 다이옥산 농도가 높아질 수록 오염경보발생 시간이 46초, 26초로 농도에 비례에서 경보발생시간은 감소함을 알 수 있다. 이렇게 발생한 경보는 통합 모니터링 시스템을 통해 문자, 전광판 등을 통해 즉시 
전달되어 즉각적인 처리가 가능하다.

\section{3. 결론}

본 논문에서는 발광미생물을 이용하여 권역별 수질변화를 측정하고 분석하여 오염을 막을 수 있는 통합 모니터링 시스 템수질오염 감시 시스템에 대한 구조와 특징 및 기능들에 대해 살펴보았다. 성능분석을 위한 실험으로는 다이옥산의 농도를 각각 $50 \mathrm{ppb}, 500 \mathrm{ppb}, 1000 \mathrm{ppb}$ 으로 하여 투입하였 을 경우의 경보 발생 trend 실험을 수행하였다. 실험 결과로 는 다이옥산 농도가 높아짐에 따라 다이옥산 유입 시간 대비 경보 발생시간이 현저하게 줄어듬을 확인할 수 있었으며, 이렇게 발생된 오염 경보는 즉각적으로 365 일 24시간 시스 템에 모니터링 된다. 성능 분석 결과에서 볼 수 있듯이 하천 및 호수 등의 수변지역에 대한 오염 여부를 24시간 365일 감시함으로써 안정적인 환경유지가 가능하며 광범위한 하천 및 호수 등에 대한 데이터를 수집함으로써 환경오염 및 재해 와 재난에 대한 대비책 수립을 기대할 수 있다. 뿐만 아니라, 기존의 외국에서 도입된 생물학적 수질감시 시스템에 비해 순수 국내에서 개발된 최첨단 융합 시스템으로서, 다양한 센서 를 인티그레이션한 시스템으로 환경변화를 측정하는 시스템 의 운영기술에 대한 기술적 토대를 마련 할 수 있다. 이러한 기술적, 환경적 효과뿐만 아니라, 순수 국내에서 개발된 제품 으로 외산 대비 기술적/경제적으로 월등한 경쟁력을 가짐으 로서 막대한 수입대체 효과를 기대할 수 있으며, 하천 및 호 수에 대해 수집된 광범위한 데이터를 기반으로 재해/재난 대비책을 마련하여, 환경오염이나 각종 재난 및 자연재해로 부터 발생하는 막대한 손실 비용을 줄일 수 있는 경제적 효과 또한 기대할 수 있다.
감사

본 연구는 중소기업청에서 지원하는 2010년도 산학연공동 기술개발사업 (No. 92492010021)의 연구수행으로 인한 결과물임.

\section{References}

1. Krenkel, P. A. and V. Novotny (1980) Water Quality Management. Academic Press.

2. Quano, E. A. R., B. N. Lohani, and N. C. Thanh (1978) Water Pollution Control in Developing Countries. Asian Institute of Technology.

3. Kim, J. Y. (2007) A policy issue for u-city construction revitalization. TTA journal 112: 55-59.

4. Ministry of land, transport and maritime affairs (2008) U-based eco space construction technology. $u$-Eco city development agency detailed planning research report.

5. Harper, J., M. George, and K. Tate (1998) Water pollution control legislation and rangelands. Rangeland watershed program fact sheet, no. 8.

6. Hur, H. W., S. K. Park, K. Y. Chung, H. Kang, and S. I. Lee (2004) Nitrogen and phosphorus removal from swine wastewater by intermittently aerated dynamic-flow system. Water Sci. Technol. 49: 367-378.

7. C. P. Leslie Grady, Jr., T. Glen Daigger, Henry C. Lim, and Marcel Dekker (1999) Biological Wastewater Treatment, Printed in the United States of America, 2nd edition.

8. Cobourn, J. (1999) Integrated watershed management on the truckee river in Nevada. J. Am. Water Resour. Assoc. 35: 623-632.

9. B. Paul (1999) Pollution control with variable production process. J. Public Economics 8: 357-367. 